\title{
LINGUA FRANCA IN THE LINGUISTIC LANDSCAPE OF GRESIK KOTA BARU
}

\author{
Adinda Rizki Ramadhani \\ adindarizkiramadhani@gmail.com \\ Universitas Airlangga
}

\begin{abstract}
In multilingual society, a language that the majority of people understand is in need. That kind of language in sociolinguistics is known as lingua franca. Lingua franca does not only appear in the way people communicate with each other, but also in the linguistic landscape of a site. By applying qualitative method, this study analyzes 48 restaurants'names as the linguistic landscape in Gresik Kota Baru (GKB), a business center in Gresik Regency. Additionally, this study attempts to identify the most-used language in that area as well as to see which language roles as the lingua franca in the linguistic landscape of GKB. In results, it is discovered that Bahasa Indonesia acquires the highest number of occurrence, which is in 27 restaurants, whilst English are spotted in 21 restaurants' names. In other words, the result implies that in $G K B$, seen from the restaurants' names as the linguistic landscape, the lingua franca is Bahasa Indonesia.
\end{abstract}

Keywords: Gresik Kota Baru, lingua franca, linguistic landscape, sociolinguistics

\begin{abstract}
Abstrak
Pada masyarakat multibahasa,bahasa yang dipahami oleh sebagian besar masyrakat sangat dibutuhkan. Bahasa tersebut di dalam sosiolinguistik dikenal sebagai lingua franca. Lingua franca tidak hanya muncul pada cara orang-orang berkomunikasi satu-sama lain, tetapi juga pada lanskap linguistik di suatu wilayah. Dengan menggunakan metode kualitatif, kajian ini menganalisis 48 nama tempat makan sebagai media untuk menilik lanskap linguistik di wilayah Gresik Kota Baru (GKB), sebuah pusat bisnis di Kabupaten Gresik. Kemudian, studi ini mencoba untuk mengidentifikasi bahasa yang paling sering digunakan di area tersebut sekaligus melihat bahasa mana yang menjadi lingua franca di lanskap linguistik di GKB. Hasilnya menunjukkan bahwa Bahasa Indonesia menjadi bahasa yang paling banyak ditemui, yakni pada 27 nama rumah makan, sementara 21 rumah makan menggunakan Bahasa Inggris sebagai nama. Dengan kata lain, hasil penelitian ini mengindikasikan bahwa di GKB, dilihat dari nama restoran sebagai lanskap linguistik, Lingua Franca yang ada adalah Bahasa Indonesia.
\end{abstract}

Kata Kunci: Gresik Kota Baru, lingua franca, lanskap linguistik, sosiolinguistik

\section{INTRODUCTION}

Public places, especially those in urban area, somehow can be seen as a place which more than one language can be spotted on. The mixing of those languages can be found not only in the way people talk to each other, but also in cityscapes, known as linguistic landscape. According to Landry \& Bourhis (1997), linguistic landscape includes the language of public road signs, government building's public signs, billboards, street names, place names, even commercial shop names, located whether inside or outside buildings, that are visible to everyone (Bruyèl-Olmedo \& Juan-Garau, 2010; Muth \& Wolf, 2010). In addition, referring to Gorter \& Cenoz 
(2007), linguistic landscapes can be in form of language in posters and even graffitti. The observations of linguistic landscape are on the matter of the language use, the syntactic, and the semantic aspects (Grishaeva, 2015). The study on linguistic landscape is considered as a new study regarding multilingualism, particularly with focus on observation of public signs or written information containing language signs that exists in public area (Gorter \& Cenoz, 2007; Muth \& Wolf, 2010). Moreover, Landry \& Bourhis (1997) added that there is a relationship between linguistic landscape and language attitude in multilingual environments (Gorter \& Cenoz, 2007).

Multilingualism, as defined by European Commission (2007), is "the ability of societies, institutions, groups, and individuals to engage, on a regular basis, with more than one language in their day-to-day lives" (Cenoz, 2013). In other words, an environment in which the people speak or write by using more than two languages can be said as a multilingual society. In present days, it is almost impossible to find monolingual societies since most people in every part of the world are multilinguals in their own levels, or else to say, in different level from one another (Ferdiyanti, 2016). Sridhar \& Wardhaugh (2002) in Ferdiyanti (2016) added that even when someone only knows several terms in more than one or two languages, such as terms in greetings, technical vocabulary, even the simplest grammatical structure, s/ he can be considered as a multilingual person. Thus, based on the definition given by Sridhar \& Wardhaugh (2002), it does make sense that linguistic landscape, which includes any kind of public signs, is believed having relations with multilingualism, providing at some points, public signs are written in more than one or two languages.

Providing in multilingualism environment too many languages are involved, the existence of one particular language understood by the majority is essential. The language is known as lingua franca. Encyclopedia of Britannica termed lingua franca as "language used in means of communication between populations speaking vernacular that are not mutually intelligible" (European Commission, 2010). In other words, it can be stated that lingua franca is the language used to "facilitate communication between people whose mother language are different" (Barotchi, 1994 in Wardhaugh, 2015). In Indonesia, Bahasa Indonesia is the lingua franca (European Commission, 2010). This, according to European Commission (2010), is because during the colonialism, Bahasa Indonesia was not the language of the elite, thus, it was used by Indonesian people as a 'secret' way to communicate.

The highest chance of spotting public signs by using more than two languages is in big cities, especially in shopping and industrial sector (Gorter \& Cenoz, 2007). However, interestingly, the multilingualism of public signs is also found in a small town near Surabaya City, the Capital of East Java Province: Gresik Regency. Gresik Regency is located in the Northwest of Surabaya City. Although Gresik Regency is a small town, the industrial sector in that town is growing rapidly throughout the years, especially in 
the development of public places and factories (Kabupaten Gresik, n.d.). The fact that Gresik Regency is near from Surabaya City, which is the second busiest city in Indonesia, pushes Gresik Regency to be more prominent in using more than its original languages, Gresik language or Javanese. This can be seen from public signs in Gresik Regency, especially those that are located in the business center sub districts, namely Gresik Sub District, Manyar Sub district, and Kebomas Sub District (Kabupaten Gresik, n.d.).

Among the business centers in Gresik Regency, there is one business center or a cluster located in Kebomas Sub District which development is accelerated, whether in the culture or in the multilingualism, named Gresik Kota Baru (henceforth GKB). The growth of the multilingualism in Gresik Regency, especially in GKB, might be because the business rhyme in Surabaya has affected the business sector in GKB, including the use of more than one language in public signs or linguistic landscape of the town. Because of that, this study aims to analyze the language used in the linguistic landscape of GKB. The linguistic landscape observed is in the form of restaurants' names. In particular, this study focuses to compare which language that is used the most in the restaurants' names of GKB. Other than that, this study is determined to discover whether English as lingua franca in the globe also plays a role as lingua franca in GKB, seen from the linguistic landscape.

Even though linguistic landscape is considered as a new study in linguistics, there are quite a lot of research on linguistic landscape. However, the studies on the relationship between linguistic landscape and lingua franca can still rarely be discovered. One of the studies found regarding linguistic landscape and lingua franca is the one authored by Torkington in 2009, which attempted to figure out the case of linguistic landscape of the billboards in the area of tourist resort named 'Golden Triangle' in Algarve, Portugal. By applying mixed method in data analysis, Torkington came to a result that most of the signs or the billboards were written in English, spotted in more than $50 \%$ of the data, making English as the lingua franca of 'Golden Triangle' (Torkington, 2009). Another study was conducted by Bruyèl-Olmedo \& Juan-Garau in 2010. By discovering the linguistic landscape in S'Arenal in Mallorca, Balearic Island, Spain, they attempted to analyze the use of English as lingua franca in that resort's linguistic landscape. In result, Bruyèl-Olmedo \& Juan-Garau concluded that English had received special treatments as lingua franca in S'Arenal beach's linguistic landscape (Bruyèl-Olmedo \& Juan-Garau, 2010). The next study was written by Fardau Bamberger in 2016. By analyzing the data she took from three different areas on the island of Aruba, namely Oranjestad (the capital of Aruba, northwest area), Noord (northern area), and San Nicolas (southeast area), she obtained the results that English is the most language used in public signs of those three different areas. This proved that the theory of English as lingua franca especially in tourism centers is correct, upper-leveling Papiamento as the local language of Aruba (Bamberger, 2016). 
From the three studies correlated with lingua franca and linguistic landscape describedabove, itcan be seen thatall of those came with the same conclusion: thatEnglish is the most language used as lingua franca, especially in linguistic landscape found in business centers or tourist destinations. Thus, this study is conducted in hopes that it can fill the gaps of the previous studies. In particular, this study is expected to give different results regarding English as the lingua franca in linguistic landscape of business centers instead of tourism destinations. Moreover, all of the previous studies were conducted in big scale of areas, whereas this study only covers small scale of area in Gresik Regency.

\section{METHODOLOGY}

This study is conducted in business and industrial center of Gresik Regency, a cluster area known as Gresik Kota Baru (GKB) in Kebomas Sub District. The data collection was done by taking pictures of the restaurants located along the main streets of GKB, namely Kalimantan Street, Jawa Street, and Sumatra Street. In total, there were 48 restaurants established in those three main streets by the time this study was conducted. As to discern, the data taken for research regarding linguistic landscape could be changing throughout the time and might not be the same as the data used in this study in several years. Meanwhile, in data analysis, qualitative approach was applied because the data are not statistical and the elucidation of the collected data was based on the writer's interpretation (Creswell, 2009). In doing the analysis, after obtaining the data as mentioned formerly, the first step done was inputting the data to Microsoft Excel, with focus on the name of the restaurants, the slogans, and the language used in those two aspects. After that, the language used in both the name of the restaurants and the slogans were grouped, whether it is Bahasa Indonesia, English, or any other language. Next, the interpretation of the language grouping was made to figure out which language is the most-used language in the data. As for the last, the conclusion was drawn to make it clearer which language is the lingua franca in the linguistic landscape of GKB.

\section{RESULTS AND DISCUSSION}

Usually, theobservation oflinguistic landscapeis conducted in big scales or in public signs as conducted by Torkington (2009), Bruyèl-Olmedo \& Juan-Garau (2010), and Bamberger(2016). Nonetheless, this study is attempted toobserve the linguistic landscape in a business center of a small town. In particular, the linguistic landscape examined are the restaurants' names in three main streets of the business center, GKB cluster, to figure out whether English still plays the role as lingua franca in business or industrial centers.

After gathering the pictures of the restaurants in three main streets of GKB, namely Kalimantan Street, Jawa Street, and Sumatra Street, it was found that there were 48 restaurants spreading along the way. GKB is a cluster that is also one of business centers in Gresik Regency. Those 48 restaurants' names are considered as linguistic landscape, 
providing according to Landry \& Bourhis (1997), restaurants' names are included in public signs. To assist the data analysis, the 48 data obtained are put in the tables as presented below, in which the language of the restaurant's name is written as "LoR".

Table 1. The languages used in restaurants' names in GKB

\begin{tabular}{|c|c|c|}
\hline No & LoR & Restaurant's Name \\
\hline 1 & Chinese Mandarin & Dimsum \& Suki Manan \\
\hline 2 & English & Adventure \\
\hline 3 & English & Andho Coffee \\
\hline 4 & English & Authentic Satay \\
\hline 5 & English & Chemilkstry Tea, Chocolate, Milk \\
\hline 6 & English & Chicken Day \\
\hline 7 & English & Evolutea Kitchen \& Coffee \\
\hline 8 & English & McDonald's \\
\hline 9 & English & Nuez Resto \& Café \\
\hline 10 & English & Panties Pizza \\
\hline 11 & English & Pizza Time \\
\hline 12 & English & Toby's \\
\hline 13 & English & Veranda Pasta House \& Café \\
\hline 14 & English & WCP Coffee \& Resto \\
\hline 15 & English, Bahasa Indonesia & Milk Moo Kedai Susu \\
\hline 16 & French, English & Favorisé Kitchen \\
\hline 17 & Bahasa Indonesia & Angkringan Jogja Jogokaryan \\
\hline 18 & Bahasa Indonesia & Bakso \\
\hline 19 & Bahasa Indonesia & Dimsum \& Suki Manan \\
\hline 20 & Bahasa Indonesia & Adventure \\
\hline 21 & Bahasa Indonesia & Andho Coffee \\
\hline 22 & Bahasa Indonesia & Authentic Satay \\
\hline 23 & Bahasa Indonesia & Kopi Santai \\
\hline 24 & Bahasa Indonesia & Majelis Mie \\
\hline 25 & Bahasa Indonesia & Mie Ayam \& Ayam Goreng Alfa \\
\hline 36 & Bahasa Indonesia & Mie Kluntung Warkos \\
\hline 27 & Bahasa Indonesia & Nasi Bebek Bu Jayanti \\
\hline 28 & Bahasa Indonesia & Nasi Goreng Kampung Raja \\
\hline 29 & Bahasa Indonesia & Pecel Malam Gembira \\
\hline 30 & Bahasa Indonesia & Roti Maryam Salman \\
\hline 31 & Bahasa Indonesia & Rumah Makan Carita \\
\hline 32 & Bahasa Indonesia & Special Nasi Bebek Sinjay Cabang Bangkalan \\
\hline 33 & Bahasa Indonesia & Waroeng Iga Karto \& Penyetan \\
\hline 34 & Bahasa Indonesia & Warung Nasi Krawu "Bu Azza” \\
\hline 35 & Bahasa Indonesia, English & Hisana Fried Chicken \\
\hline
\end{tabular}




\begin{tabular}{lll}
\hline $\mathbf{3 6}$ & Bahasa Indonesia, English & Kampoeng Steak \\
\hline $\mathbf{3 7}$ & Bahasa Indonesia, English & Kedai Delfino Pizza \& Bakery \\
\hline $\mathbf{3 8}$ & Bahasa Indonesia, English & Kepiting Tempeh Seafood \& Ikan Bakar \\
\hline $\mathbf{3 9}$ & Bahasa Indonesia, English & Sang Omah Delodjie Resto \& Ice Cream \\
\hline $\mathbf{4 0}$ & Bahasa Indonesia, Javanese & Ayam Penyet Suroboyo \\
\hline $\mathbf{4 1}$ & Bahasa Indonesia, Javanese & Bakso Gibrass \\
\hline $\mathbf{4 2}$ & Bahasa Indonesia, Javanese & Sambal Lalap Wong Solo \\
\hline $\mathbf{4 3}$ & Italian & Mia Pizza Italiana \\
\hline $\mathbf{4 4}$ & Japanese & Dora-Yaki Yakiniku Shabu Shabu \\
\hline $\mathbf{4 5}$ & Japanese & Ichi Sushi \\
\hline $\mathbf{4 6}$ & Japanese, English & J'Sushi Japanese Food Resto \& Caffe \\
\hline $\mathbf{4 7}$ & $*$ & Jank Jank \\
\hline $\mathbf{4 8}$ & $*$ & Wakacao \\
\hline
\end{tabular}

Based on table 1 above, it can be perceived that the 48 restaurants found in three main streets of GKB have various languages. Out of 48 restaurants, one of those is spotted using Chinese Mandarin language $(\mathrm{Cmn})$ as the restaurant's name. Moreover, based on the table, the restaurants that use only English (En) as the names of the restaurants are 13 places. After that, the combination of French (Fr) and English (En) appears in 1 restaurant. The use of Bahasa Indonesia (Id) only are discovered in 18 restaurants' names, tailed by the use of combination of English (En) and Bahasa Indonesia (Id) that are noticed in 7 restaurants' names. Not only the combination of two languages, 1 restaurant is found using three languages in its restaurant's names, namely Bahasa Indonesia (Id), English (En), and Javanese (Jv). Furthermore, the combination of Bahasa Indonesia (Id) and Javanese (Jv) are recognized in 3 restaurants' names, while the use of Italian (It) is found only in 1 restaurant's names. Other than that, the use of Japanese (Jp) is also found in the restaurants' names in GKB, particularly in 2 restaurants, whereas Japanese (Jp) combined with English (En) is only spotted in 1 restaurant's name. In addition, there are 2 restaurants' names which languages are unidentified, symbolized by $(*)$ in table 1 above. However, in data analysis and interpretation, the unidentified language is not included in the data any longer.

To ease the interpretation of the obtained data, table 2 below depicts the number of each language used in the 48 restaurants as the objects of this study. Additionally, the numbers in the table below are sorted from the highest one to the lowest one. The numbers of the restaurants is written as "NoR" in the following table. 
Table 2. The numbers of language used in restaurants' names

\begin{tabular}{|c|c|c|c|}
\hline No & LoR & NoR & Classification \\
\hline \multirow[t]{4}{*}{1} & Bahasa Indonesia (Id) & 27 & • 18 (Id) only \\
\hline & & & - $5(\mathrm{Id}-\mathrm{En})$ \\
\hline & & & - $3(\mathrm{Id}-\mathrm{Jv})$ \\
\hline & & & - $1(\mathrm{Id}-\mathrm{En}-\mathrm{Jv})$ \\
\hline \multirow[t]{5}{*}{2} & English (En) & 21 & • 13 (En) only \\
\hline & & & - $5(\mathrm{En}-\mathrm{Id})$ \\
\hline & & & - $1(\mathrm{En}-\mathrm{Fr})$ \\
\hline & & & - $1(\mathrm{En}-\mathrm{Jp})$ \\
\hline & & & - $1(\mathrm{En}-\mathrm{Id}-\mathrm{Jv})$ \\
\hline \multirow[t]{2}{*}{3} & Javanese (Jv) & 4 & • $3\left(J_{V}-\mathrm{Id}\right)$ \\
\hline & & & - $1(\mathrm{Jv}-\mathrm{Id}-\mathrm{En})$ \\
\hline \multirow[t]{2}{*}{4} & Japanese (Jp) & 3 & - 2 (Jp) only \\
\hline & & & - $1(\mathrm{Jp}-\mathrm{En})$ \\
\hline 5 & Italian (It) & 1 & - 1 (It) only \\
\hline 6 & French $(\mathrm{Fr})$ & 1 & - $1(\mathrm{Fr}-\mathrm{En})$ \\
\hline 7 & Chinese Mandarin $(\mathrm{Cmn})$ & 1 & - $1(\mathrm{Cmn})$ only \\
\hline
\end{tabular}

The table pictured that the most-used language in restaurants' names in GKB is Bahasa Indonesia, with the occurrence of 27 times, whether it is monolingual (Bahasa Indonesia only) or bilingual and trilingual. English is the second most-used language with the occurrence of 21 times. Interestingly, Javanese as the local language of Gresik Regency only appears in 4 restaurants, having only one difference with Japanese, which emerges in 3 restaurants. In addition, Italian, French, and Chinese Mandarin have the same rate of occurrence, which is in 1 restaurant. As for the restaurants with undefined language, as aforementioned, those restaurants are excluded from the data.

The emergence of Italian, French, and Chinese Mandarin as languages in 3 different restaurants' names depicts that Gresik Regency has 'visitors' who settled there and build some businesses. This can be seen from the food that those restaurants sell. For example, the restaurant with Italian naming, "Mia Pizza Italiana", provides pizza as their main menu, which undeniable that pizza is Italian traditional dish. The similar thing also happens in French-named restaurant, "Favorisé Kitchen" that sells pasta as their main dish and Chinese Mandarin-named restaurant, "Dimsum \& Suki Manan", which in obvious, offers Chinese traditional cuisine, dimsum. In addition, the occurrence of the restaurants with Japanese naming, "Dora-Yaki Yakiniku Shabu Shabu" and "Ichi Sushi", sell Japanese cooking as yakiniku and sushi. In broad, the appearance of those restaurants represents the multilingualism in Gresik Regency, specifically in GKB cluster.

The local language of Gresik Regency, Javanese, is also found in some of the restaurants' names. In total, there are 4 restaurants that use Javanese as their naming. 
The findings of Javanese language in the data are not shocking. In obvious, Gresik Regency is located in Java Island in which the majority of people speak Javanese. Even though Gresik language is not spotted even once in the 48 restaurants as the objects of this study, the use of Javanese in 4 out of 48 restaurants has proven enough that Javanese or local language is still usable in the globalization era. In other words, Javanese language is included in the multilingualism circle of Gresik Regency, particularly the multilingualism in business centers as GKB cluster, although the language is combined with another language in each of 4 spotted restaurants.

As a business area located near Surabaya City, it is not surprising that the use of English has increased in GKB cluster, notably, in the linguistic landscape in the form of restaurants' names. Based on the data, the use of English is discovered in 21 restaurants, whether it is one language-used or combined with another language. Similar to the previous studies aforementioned, in this study, English seems having a special place in business centers. However, it does make sense that English is found in almost half of the data, providing the status of English as the international language (Seidlhofer, 2004 in Majanen, 2008). Other than that, the choice of using English instead of another language in restaurants' names in GKB might correlate with globalization, which strengthen the flow of multilingualism in that area.

Although it is stated in quite a lot research that English is the 'main' language of business center, in this study, the data has proven that Bahasa Indonesia is the most-used language of the linguistic landscape in the form of restaurants' names in GKB cluster. This is interesting because it upholds different result conducted in business centers. In elucidation, even if the people in Gresik Regency, particularly in GKB cluster are trying to keep up with the multilingualism flow as it is, perhaps, in Surabaya as the second big city in Indonesia, they still use Bahasa Indonesia more than they use foreign languages. Other than that, the restaurants found using Bahasa Indonesia as their names, particularly those that use Bahasa Indonesia only, are admitted selling Indonesian foods, such as bakso, nasi goreng, pecel, and nasi krawu, a local food of Gresik Regency. In broad, this can be perceived that Bahasa Indonesia still lingers in Gresik people's heart as their identity even when they are in the middle of multilingualism and globalization.

To resume the interpretation, different from all three research explained in the background which results proved that English plays as the lingua franca in big scale of public places, it can be affirmed that the use of Bahasa Indonesia outnumbered the use of other languages including English, Javanese, French, Italian, Japanese, and Chinese Mandarin. The different result with the previous studies might occur due to the scope of this research that only focused in small area (a cluster). However, this can be perceived that even though GKB cluster is a business center with multilingual environment, the influence of foreign language does not outperform Bahasa Indonesia. In other words, Bahasa Indonesia is the lingua franca of linguistic landscape in 
GKB cluster, in terms of restaurants' names. Additionally, Bahasa Indonesia as the lingua franca is possibly caused by the language used by the people in every day situation. This is, likewise, in line with Seidlhofer's (2004) theory in which he claimed that lingua franca is the language that all people can communicate with (Majanen, 2008). In this case, Bahasa Indonesia is the lingua franca because the people comprehend it more than they do other languages, including foreign languages.

\section{CONCLUSION}

By observing 48 restaurants along the main streets of GKB cluster, in conclusion, it can be uttered that despite the existence of multilingualism in that cluster, the most language used in the linguistic landscape in terms of restaurants' names is Bahasa Indonesia. In details, the use of Bahasa Indonesia is found in 27 restaurants. On the other hand, English that is believed to be global language are only spotted in 21 restaurants' names. This proves that even though globalization and the rapid flow of multilingualism occur in GKB cluster, the people there are still proud of using Bahasa Indonesia and showing it as their identity. The identification can be seen through the menu that they serve in their restaurants, which most of them are Indonesian traditional cuisines. Several studies have been declared that English is the lingua franca of business centers, including industrial area and tourism destinations. However, the declaration does not match with this study's result. In small area, such as GKB in Gresik Regency, the lingua franca depicted in the linguistic landscape is the national language of Indonesia, Bahasa Indonesia. The widespread use of Bahasa Indonesia is perhaps caused by the multilingual level of the people itself; that they understand Bahasa Indonesia more than they do other languages. Thus, the restaurants' owners name their business by using Bahasa Indonesia to make other people more aware of what they sell as well as to show their identity that they are Indonesians. In addition, the observations regarding lingua franca in another form of linguistic landscape of business centers in different area is expected to be done in the future.

\section{REFERENCES}

(n.d.). Retrieved from Kabupaten Gresik: http://gresikkab.go.id

Bamberger, F. (2016). The Role of English in Aruba's Linguistic Landscape. University of Utrecht - Faculty of Humanities.

Bruyèl-Olmedo, A., \& Juan-Garau, M. (2010). English as a Lingua Franca in the Linguistic Landscape of the Multilingual Resort of S'Arenal in Mallorca. International Journal of Multilingualism, 6(4), 386-411.

Cenoz, J. (2013). Defining Multilingualism. Annual Review of Applied Linguistics, 33, 3-18. 
Creswell, J. W. (2009). Research Design: Qualitative, Quantitative, and Mixed Methods Approaches (3rd ed.). Lincoln: SAGE Publications. Inc.

European Commission. (2010). Lingua Franca: Chimera or Reality? Luxembourg: European Union.

Ferdiyanti, I. N. (2016). Multilingualisme dalam Lanskap Linguistik di Wilayah Kota Surabaya. Post-graduate Thesis. Surabaya: Universitas Airlangga.

Gorter, D., \& Cenoz, J. (2007). Knowledge about language and linguistic landscape. Encyclopedia of Language and Education, 1-13.

Grishaeva, E. B. (2015). Linguistic Landscape of the City of Krasnoyarsk. THE XXVI ANNUAL INTERNATIONAL ACADEMIC CONFERENCE, LANGUAGE AND CULTURE. 200, pp. 210-214. Procedia - Social and Behavioral Sciences.

Majanen, S. (2008). English as a Lingua Franca: Teacher's Discourses on Accent and Identity. Master of Arts Thesis. University of Helsinki.

Muth, S., \& Wolf, F. (2010). The Linguistic Landscape of Chişinău: Forms and Functions of Urban Public Verbal Signs in a Post-Soviet Setting. Postgraduate Conference in Linguistics \& Language Teaching. 4, pp. 1-21. Lancaster University.

Torkington, K. (2009). Exploring the Linguistic Landscape: the Case of the 'Golden Triangle' in the Algarve, Portugal. Lancaster University Postgraduate Conference in Linguistics \& Language Teaching. 3, pp. 122-145. Lancaster: Lancaster University.

Wardhaugh, R., \& Fuller, J. M. (2015). An Introduction to Sociolinguistics (7th ed.). New Jersey: Wiley-Blackwell. 